\title{
Rail-Roading Technique Using 18 Gauge Intravenous Catheter and Silicon Rod for Frontalis Suspension in Blepharophimosis Syndrome
}

\author{
Ruchi Goel $^{*}, 1$, A.G. Apoorva ${ }^{1}$, Sparshi Jain ${ }^{1}$, K.P.S. Malik², Smriti Nagpal ${ }^{1}$ and Divya Kishore ${ }^{1}$ \\ ${ }^{I}$ Gurunanak Eye center, Maulana Azad Medical College, New Delhi, India \\ ${ }^{2}$ Subharti Medical College, Meerut, Uttar Pradesh, India
}

\begin{abstract}
Silicon rods are widely employed for frontalis sling suspension. However, on passing through the tissues, at times, the silicon rod gets detached from the stainless steel needle. This occurs more commonly in patients of blepharophimosis syndrome, in which hypoplasia of superior orbital rim with deficiency of skin between lid and brow, causes difficulty in passage of the needle when it is manipulated upwards from lid towards the brow. To overcome these problems we describe the use of an $18 \mathrm{G}$ intravenous catheter to railroad the needle with the silicon rod, obviating the blind upward maneuvers with the needle and protecting against the damage to the silicon rod -needle assembly. The technique is easily reproducible, safe and can be used in all silicon rod suspensions.
\end{abstract}

Keywords: Blepharophimosis syndrome, intravenous catheter, ptosis, silicon sling, technique.

\section{INTRODUCTION}

Brow suspension procedures have been in use since $1880 \mathrm{~s}$ when Dransart first used buried catgut sutures to suspend eyelid to eyebrow in cases with inadequate levator function [1]. Payr's implementation of thigh fascia in 1909 marked a significant advancement in autologous sling surgeries [2]. Since then various materials have been tried for brow suspension including non- absorbable sutures, skin slips, muscle slips, banked sclera slips, autogenous fascia lata and silicon sling.

The use of silicon bands was first described in 1966 by Tillett and Tillett [3]. In 1977, Rowan and Hayes started the use of $0.8 \mathrm{~mm}$ silicon rods premounted on $0.9 \mathrm{~mm}$ stainless steel needle [4]. Silicon sling has gained widespread acceptance due to its ease of use, less surgical time and minimal patient morbidity. Silicon sling is the procedure of choice in certain cases of bilateral ptosis with poor levator function, particularly in blepharophimosis syndrome and also as a temporary procedure in severe unilateral ptosis to prevent amblyopia [5]. The silicon rods, during the passage become blunt and at times get detached from the stainless steel portion. In blepharophimosis syndrome, there is hypoplasia of superior orbital rim with severe deficiency of skin between lid and brow. This adds to the difficulty when the needle is passed upwards from lid towards the brow leading to frequent detachments of silicon rod.

The Wright's needle, a standard tool for the management of frontalis suspension, measures $2 \mathrm{~mm}$ in diameter with an eye at its tip for the introduction of fascia lata [6]. In the event of needle detachment, Wright's needle can be used to guide the silicon rod but it requires larger openings and the tip often gets blunted by repeated use leading to tissue drag.

*Address correspondence to this author at the 513/514, First Floor, Double Storey, New Rajinder Nagar, New Delhi-110060, India; Tel: 9811305645; E-mail: gruchi1@rediffmail.com
In an effort to reduce scarring and swelling, various guide needles like epidural needle [7], 18 gauge hypodermic needle [8], 18 gauge intravenous catheter needle [9] and abdominal needle [10] have been used. However, the epidural and abdominal needle are excessively malleable. The 18 gauge hypodermic needle for passage of silicon rod [8] requires removal of premounted needles from the rods. Also, the authors reported occurrence of the silicon rod breakage by the needle tip in two patients.

We describe a new technique of managing complicated ptosis, in blepharophimosis syndrome using silicon sling and guiding its passage using 18 gauge intravenous catheter allowing smooth passage of the silicon rod. The 18 gauge intravenous catheter had previously been used with 2,0 prolene suture.

\section{SURGICAL TECHNIQUE}

Under local anesthesia, the lid sutures were passed in the upper lid. The lid plate was placed to protect the globe and standard incision sites of the Fox's method were marked on the lid and forehead. The lid marks were made $3 \mathrm{~mm}$ above the lid margin. The brow incision sites were marked on the brow slightly medial and lateral to the medial \& lateral lid incision sites respectively. The superior brow incision site, 1 $\mathrm{cm}$ superior and central to both the brow incisions, was deepened with tenotomy scissors to bury the silicon rod ends. In the left eye silicon sling was passed starting from superior brow incision medially in an anti-clockwise direction. At the time of passing the sling from the lateralmost lid incision up wards towards the lateral brow incision, a lot of resistance was encountered, possibly due to the thin tarsus and the deficient orbital rim. As the sling was not passing through, despite, repeated attempts, to prevent further damage to soft tissues, an 18 gauge intravenous catheter (internal diameter $1.03 \mathrm{~mm}$, outer diameter $1.2 \mathrm{~mm}$, $30 \mathrm{~mm}$ in length) was passed along with the stilette in place 
through the lateral brow incision downwards towards the lateral lid marking to make a tract, the stilette was then withdrawn and the sling attached to its steel needle $(0.9 \mathrm{~mm}$ outer diameter) was engaged in the flexible catheter tubing (Fig. 1). The catheter was then withdrawn along with the silicon sling easily through the lateral brow incision (Fig. 2). The same procedure was carried out for bringing out the sling through the superior brow incision (Fig. 3, 4). The sling was then passed through the sleeve and tightened at the forehead to lift the lids to achieve the desired lid height and contour. The ends of the sling were trimmed. The sleeve was then buried in the superior forehead incision to prevent extrusion. The superior incision was then sutured in 2 layers using 5-0 vicryl and 6-0 silk. The other incisions were left to heal as such. Similar procedure was repeated on the other eye. Frost sutures were applied.

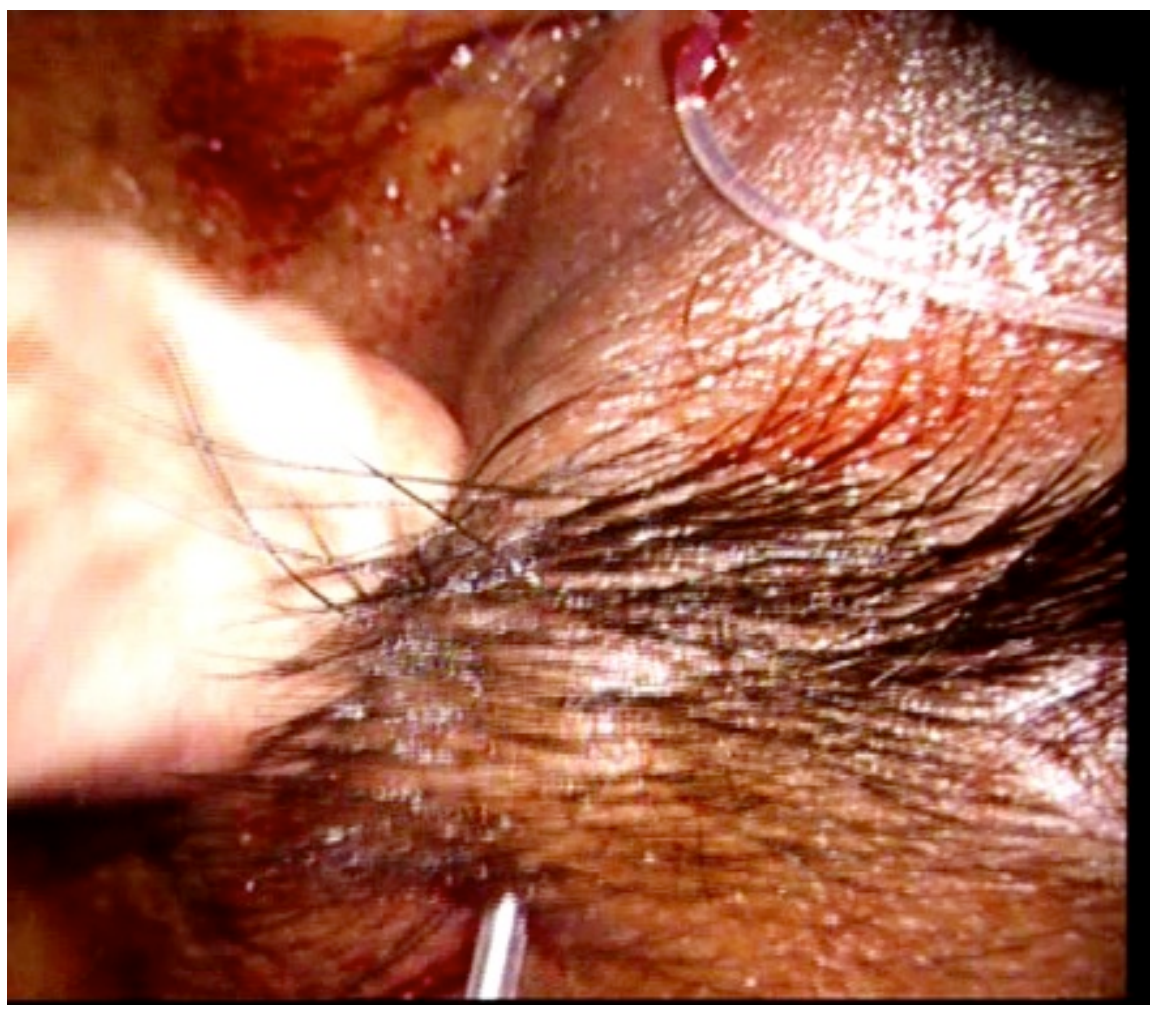

Fig. (1). The $18 \mathrm{G}$ intravenous catheter is passed from the superior brow incision to exit at the lid marking.

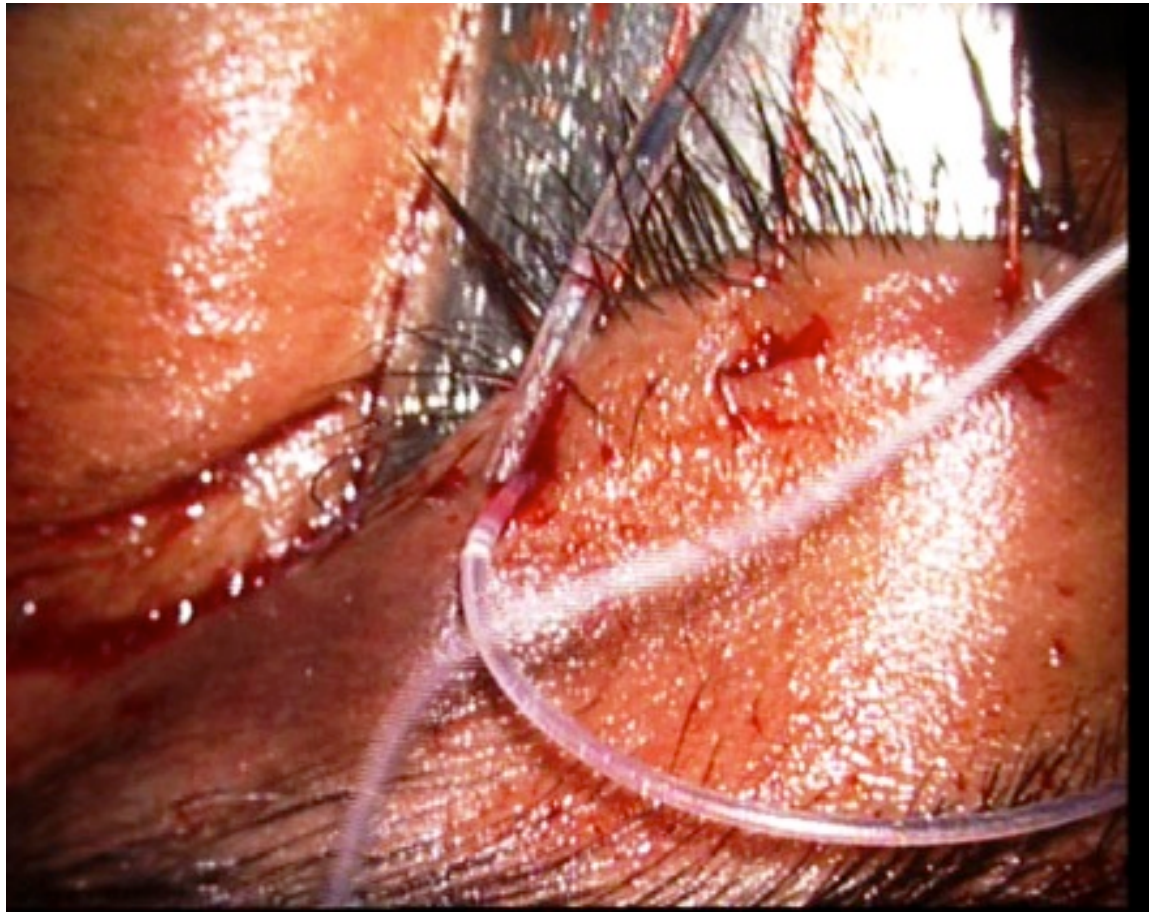

Fig. (2). The stainless steel needle attached to the silicon rod is docked into the lumen of the catheter after withdrawing the stillete. 


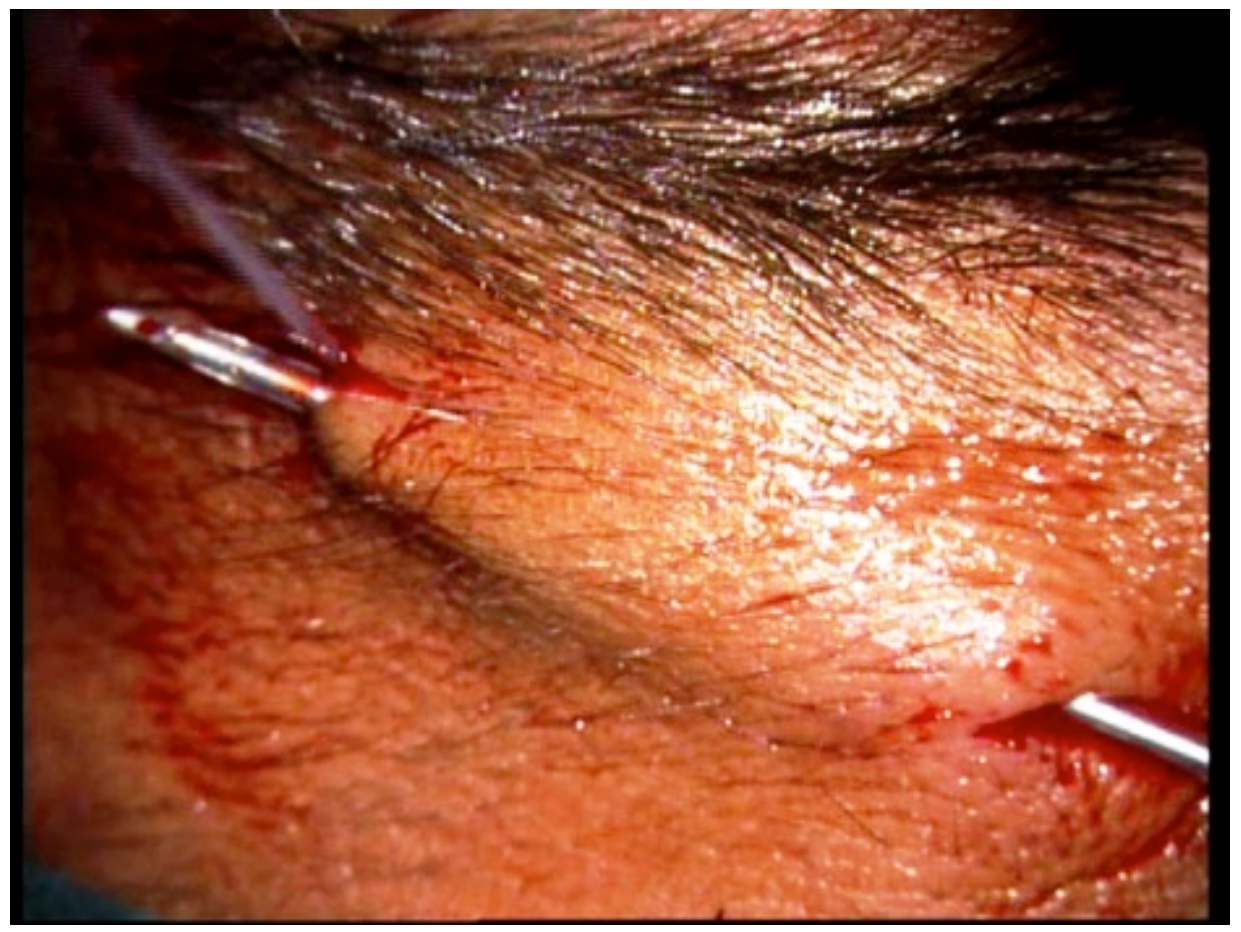

Fig. (3). The $18 \mathrm{G}$ intravenous catheter is passed from the central incision to the brow incision marking.

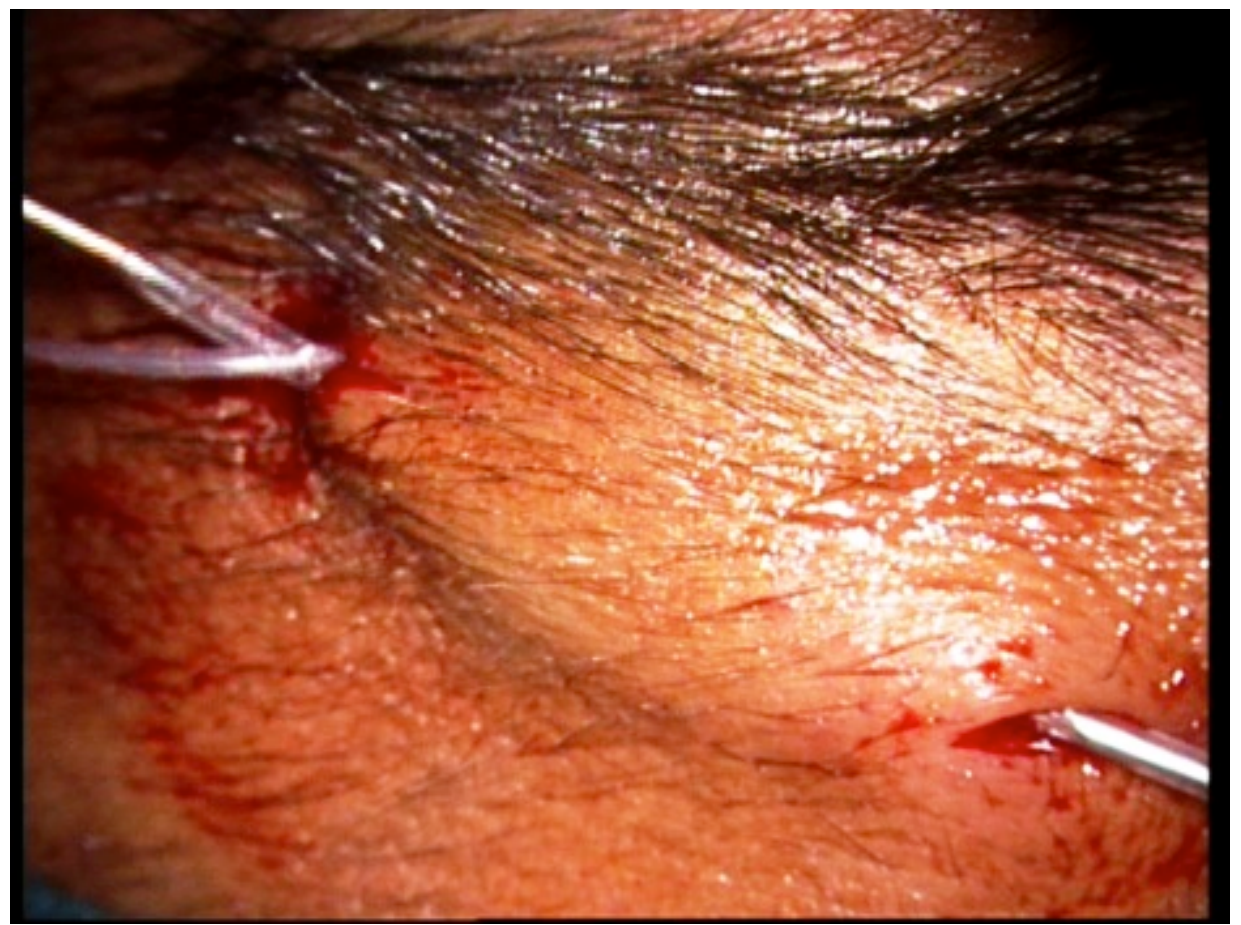

Fig. (4). The needle is docked into the catheter and the catheter is pulled out carrying the needle attached to the silicon rod.

\section{DISCUSSION}

Blepharophimosis, ptosis, epicanthus inversus syndrome (BPES) is defined by the presence of marked reduction in all dimensions of the palpebral fissure, ptosis associated with hypoplasia of the tarsal plates and epicanthus inversus. Telecanthus is seen in a majority of patients [11]. Computerized tomography of orbit in these patients has revealed orbital phimosis (deep and narrow orbits) [12]. Eyebrows have increased vertical height causing a pronounced convex arch due to constant contraction of frontalis muscle causing stretching of hair bearing skin. There is also associated hypoplasia of superior orbital rim with severe deficiency of vertical skin between lid and brow [13]. These abnormalities hinder the passage of silicon sling during ptosis surgery for BPES. The excessive manipulation, besides causing tissue trauma, can result in detachment of the needle from the silicon rod.

An $18 \mathrm{G}$ intravenous catheter is routinely available in all theaters and is inexpensive. The needle on which the silicon 
rod is mounted, fits comfortably in catheter after removal of its stillete and there is no need for dismembering the needle from silicon rod. Also, the sharp tip of the stillete, slender body and the stiffness of the catheter renders ease of manipulation. The pulling force at the junction of the stainless steel needle and the silicon rod is completely removed. However, care has to be exercised while passing the catheter with stillete at its exit point to keep the end of silicon rod away. Also while docking the needle into the catheter sleeve, it should be directed parallel to the sleeve, so as to avoid damage to the catheter. The scar is minimal and there is no trauma to adjacent tissues.

\section{CONCLUSION}

In conclusion, our technique of rail-roading, using 18 gauge intravenous catheter facilitates smooth passage of the silicon sling, through small incisions, is atraumatic and is helpful in difficult cases like blepharophimosis syndrome where there is deficient supra orbital rim and greater distance to be traversed between eyelid and eyebrow. This method can be readily employed by beginners in all cases of silicon rod suspension since it protects the silicon rod from breaking away from its needle.

\section{CONFLICT OF INTEREST}

The authors confirm that this article content has no conflict of interest.

\section{ACKNOWLEDGEMENTS}

Declared none.

\section{REFERENCES}

[1] Dransart HN. Un cas de blépharoptose opéré par un procédé spécial à l'auteur. Guerison. Analectes Ophtalmol 1880; 84: 88. (German)

[2] Payr E. Plastick mittels freies faszientransplantation bei ptosis. Med Verein Greipwald Deuthsche Med Wchnschi. 1908; 35: 822.

[3] Tillet CW, Tillet GM. Silicon sling in correction of ptosis. Am J Ophthalmol. 1966; 62: 521-3.

[4] Rowan PJ, Hayes GS. Silicone sling for ptosis. South Med J 1977; 70(1): 68-9.

[5] Betharia SM. Frontalis sling: a modified simple technique. Br J Ophthalmol 1985; 69(6): 443-5.

[6] Crawford JS. Repair of ptosis using frontalis muscle and fascia lata Trans Am Acad Ophthalmol Otolaryngol 1956; 60: 672-8.

[7] Daví G, Modorati G, Brancato R. A disposable needle for frontalis suspension surgery in congenital ptosis. Ophthalmic Surg Laser 1997; 28(7): 607-8.

[8] Goel S, Burkat CN. The 18-gauge needle: An innovative simple tool for frontalis sling surgery. Ophthal Plast Reconstr Surg 2012; 28(6): 424-8.

[9] Alhady M, Ngo CT, Tan AK, Chua CN. Use of 18-gauge intravenous catheter needle for frontalis suspension in children with congenital ptosis. Eye 2007; 21: 308-9.

[10] Caputo AR, Guo S, Wagner R. An alternative needle for frontalis suspension. Am J Ophthalmol 1989; 108(2): 208-9.

[11] Oley C, baraitser M. Blepharophimosis, ptosis, epicanthus inversus syndrome (BPES syndrome). J Med Gen 1988; 25: 47-51.

[12] Krastinova D, Jasinski MA. Orbitoblepharophimosis syndrome: A 16-year perspective. Plast Reconstr Surg 2003; 111(3): 987-99.

[13] Beard C. Ptosis, $3^{\text {rd }}$ ed. Missouri: C.V. Mosby Company 1981. 